\title{
Purification and Properties of an NAD(P)+-linked Formaldehyde Dehydrogenase from Methylococcus capsulatus (Bath)
}

\author{
By DAVID I. STIRLING AND HOWARD DALTON \\ Department of Biological Sciences, University of Warwick, Coventry CV4 $7 A L$
}

(Received 7 February 1978)

Crude soluble extracts of Methylococcus capsulatus strain Bath, grown on methane, were found to contain $\mathrm{NAD}(\mathrm{P})^{+}$-linked formaldehyde dehydrogenase activity. Activity in the extract was lost on dialysis against phosphate buffer, but could be restored by supplementing with inactive, heat-treated extract $\left(70{ }^{\circ} \mathrm{C}\right.$ for $\left.12 \mathrm{~min}\right)$. The non-dialysable, heat-sensitive component was isolated and purified, and has a molecular weight of about 115000. Sodium dodecyl sulphate gel electrophoresis of the protein suggested there were two equal subunits with molecular weights of 57000 . The heat-stable fraction, which was necessary for activity of the heat-sensitive protein, was trypsin-sensitive and presumed to be a low molecular weight protein or peptide. A number of thiol compounds and other common cofactors could not replace the component present in the heat-treated soluble extract. The purified formaldehyde dehydrogenase oxidized three other aldehydes with the following $K_{\mathrm{m}}$ values: $0.68 \mathrm{~mm}$ (formaldehyde); $0.075 \mathrm{~mm}$ (glyoxal); $7.0 \mathrm{~mm}$ (glycolaldehyde); and $2.0 \mathrm{~mm}$ (DLglyceraldehyde). $\mathrm{NAD}^{+}$or $\mathrm{NADP}^{+}$was required for activity, with $K_{\mathrm{m}}$ values of 0.063 and $0.155 \mathrm{~mm}$ respectively, and could not be replaced by any of the artificial electron acceptors tested. The enzyme was heat-stable at $45^{\circ} \mathrm{C}$ for at least $10 \mathrm{~min}$ and had temperature and $\mathrm{pH}$ optima of $45^{\circ} \mathrm{C}$ and $\mathrm{pH} 7.2$ respectively. A number of metal-binding agents and substrate analogues were not inhibitory. Thiol reagents gave varying degrees of inhibition, the most potent being $p$-hydroxymercuribenzoate which at $1 \mathrm{~mm}$ gave $100 \%$ inhibition. The importance of possessing an $\mathrm{NAD}(\mathrm{P})^{+}$-linked formaldehyde dehydrogenase, with respect to $M$. capsulatus, is discussed.

\section{INTRODUCTION}

Seven different types of formaldehyde dehydrogenase activity have been reported in $\mathrm{C}_{1}$-utilizing bacteria (Table 1). These various types can be roughly divided into two groups: (1) NAD(P)+-linked enzymes, and (2) NAD(P)+-independent enzymes. The enzymes in the first group include both formaldehyde-specific and non-specific aldehyde dehydrogenases, and many require glutathione for activity. The second group of enzymes all require artificial electron acceptors to assay their activity in vitro, and again some can utilize various other aldehydes as substrates. One prominent enzyme in group 2 is type 7, the ubiquitous methanol dehydrogenase, first described by Anthony \& Zatman (1964), found in all methylotrophs capable of growing on methanol and methane. The ability of this enzyme to oxidize formaldehyde and, in some cases, acetaldehyde (Sperl, Forrest \& Gibson, 1974) may be due to the substrate being predominantly in the hydrated form in solution.

Formaldehyde can also be oxidized to $\mathrm{CO}_{2}$ and water by a cyclic series of reactions involving hexulose phosphate synthase (Strøm, Ferenci \& Quayle, 1974; Colby \& Zatman, 1975). Theoretically, this pathway could generate two molecules of NAD(P)H per molecule of formaldehyde oxidized. 
Table 1. Different types of formaldehyde dehydrogenase enzymes found in $C_{1}$-utilizing bacteria

\section{NAD(P)+-linked}

Gluta- $\overbrace{\text { Gluta- }}$
thione thione in- electron

Type dependent dependent acceptor*

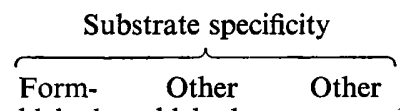

\section{Group 1}

\begin{tabular}{|c|c|c|c|c|c|c|c|c|}
\hline 1 & + & 一 & - & + & - & - & 一 & $\begin{array}{l}\text { Methylomonas methanica } \\
\text { (Texas) } \\
\text { Methylomonas methanica } \\
\text { (Iowa) } \\
\text { Pseudomonas extorquens } \\
\text { Bacterium 5H } 2 \\
\text { Protaminobacter ruber } \\
\text { Pseudomonas aminovorans }\end{array}$ \\
\hline 2 & - & + & - & + & - & - & - & Pseudomonas MS \\
\hline 3 & - & + & - & + & + & - & - & Bacterium 4B6 \\
\hline 4 & - & + & - & + & - & - & $\begin{array}{l}\text { Tetrahy- } \\
\text { drofolate }\end{array}$ & $\begin{array}{l}\text { Pseudomonas AM1 } \\
\text { Methylobacterium } \\
\text { organophilum }\end{array}$ \\
\hline \multicolumn{9}{|c|}{ Group 2} \\
\hline 5 & - & - & $\begin{array}{l}\text { DCPIP or } \\
\mathrm{K}_{3} \mathrm{Fe}(\mathrm{CN})_{6}\end{array}$ & + & - & - & - & Pseudomonas $\mathrm{RJ}_{1}$ \\
\hline 6 & - & - & $\begin{array}{l}\text { DCPIP or } \\
\text { PMS }\end{array}$ & + & + & - & - & $\begin{array}{l}\text { Pseudomonas Ам1 } \\
\text { Pseudomonas aminovorans }\end{array}$ \\
\hline 7 & - & - & PMS & + & $\left(\mathrm{CH}_{3} \stackrel{ \pm}{\mathrm{C}} \mathrm{HO}\right)$ & + & $\begin{array}{c}\mathrm{NH}_{3} \text { or } \\
\mathrm{CH}_{3} \mathrm{NH}_{2}\end{array}$ & $\begin{array}{l}\text { Methylococcus capsulatus } \\
\text { (Texas) } \\
\text { Pseudomonas } \mathrm{M} 27 \\
\text { Hyphomicrobium } \mathrm{WC} \\
\text { Pseudomonas } \mathrm{TPI} \\
\text { Pseudomonas } \mathrm{W} \\
\text { Methylosinus sporium } \\
\text { Pseudomonas } \mathrm{RJ}_{1} \\
\text { Methylobacterium } \\
\text { organophilum }\end{array}$ \\
\hline
\end{tabular}

* DCPIP, 2,6-Dichlorophenolindophenol; PMS, phenazine methosulphate.

$\dagger$ (1) Johnson \& Quayle, 1964; (2) Harrington \& Kallio, 1960; (3) Hampton \& Zatman, 1973; (4) Boulton \& Large, 1977; (5) Kung \& Wagner, 1970; (6) Colby \& Zatman, 1973; (7) Large \& Quayle, 1963; (8) O'Connor \& Hanson, 1977; (9) Mehta, 1975; (10) Patel \& Hoare, 1971; (11) Anthony \& Zatman, 1964; (12) Sperl et al., 1974; (13) Patel \& Felix, 1976; (14) Mehta, 1973.

To date, no formaldehyde dehydrogenase has been found in Methylococcus capsulatus (Texas) (Patel \& Hoare, 1971) or M. capsulatus (Bath) other than the non-specific primary alcohol dehydrogenase, present in both. This paper describes the isolation of an NAD $(P)^{+}$ linked formaldehyde dehydrogenase from $M$. capsulatus (Bath) which consists of at least two components. The purification of the heat-sensitive, non-dialysable component of the enzyme and some of its properties are also described.

\section{METHODS}

Growth of organism and preparation of soluble extracts. Methylococcus capsulatus (Bath) (Whittenbury, Phillips \& Wilkinson, 1970) was grown at $45^{\circ} \mathrm{C}$ as a batch culture on ammonium mineral salts (AMS) medium (Dalton \& Whittenbury, 1976) in a 1001 fermenter (L. H. Engineering, Stoke Poges, Buckinghamshire). Methane $(25 \%, \mathrm{v} / \mathrm{v}$, in air) was supplied as the carbon source. Cells were harvested and soluble extracts were prepared as described previously (Colby, Stirling \& Dalton, 1977).

Enzyme assay and units. Formaldehyde dehydrogenase activity was assayed spectrophotometrically by following the reduction of $\mathrm{NAD}^{+}$at $340 \mathrm{~nm}$. All assays, except where specified, were carried out in $1.5 \mathrm{ml}$ cuvettes at $45^{\circ} \mathrm{C}$. The reaction mixture contained (in $1.5 \mathrm{ml}$ ): potassium phosphate buffer, $\mathrm{pH} 7 \cdot 2,30 \mu \mathrm{mol}$; $\mathrm{NAD}^{+}, 1 \mu \mathrm{mol} ; \mathrm{KCN}, 3.75 \mu \mathrm{mol}$; and various amounts of test protein. After 3 min preincubation, the 
reaction was started by adding formaldehyde $(3.75 \mu \mathrm{mol})$. After step 1 in the purification of the heatsensitive component (HSC) of the formaldehyde dehydrogenase, the partially purified or purified HSC required the presence of heat-treated soluble extract (HTSE) to regain activity. One unit of activity was defined as the amount of enzyme required to reduce $1 \mu \mathrm{mol} \mathrm{NAD}{ }^{+} \min ^{-1}$.

Preparation of heat-treated soluble extract. The HTSE was prepared by incubating crude soluble extract at $70^{\circ} \mathrm{C}$ in a water bath for $12 \mathrm{~min}$, then centrifuging the extract for $3 \mathrm{~min}$ to remove the precipitated protein. The protein concentration of the HTSE was $16 \mathrm{mg} \mathrm{ml}^{-1}$.

Trypsin treatment of the heat-treated soluble extract. Samples of HTSE $(0.75 \mathrm{ml}, 12 \mathrm{mg}$ protein) were dispensed into four micro-centrifuge tubes $(1.5 \mathrm{ml}$ capacity). Tube 1 was kept in ice for $30 \mathrm{~min}$ and tubes 2 , 3 and 4 were incubated at $37^{\circ} \mathrm{C}$ in a shaking water bath. Before incubation, $2 \mathrm{mg}$ trypsin (280 BAEE units) was added to tube 3 , and $2 \mathrm{mg}$ trypsin plus $4 \mathrm{mg}$ trypsin inhibitor were added to tube 4 . After the $30 \mathrm{~min}$ incubation period, $4 \mathrm{mg}$ trypsin inhibitor was added to tube 3 , and then all four tubes were stored in ice.

Purification of heat-sensitive component of formaldehyde dehydrogenase. Step 1: ammonium sulphate treatment. Ammonium sulphate fractionation of $15 \mathrm{ml}$ crude soluble extract was carried out at $4{ }^{\circ} \mathrm{C}$ in the usual manner, with the fraction precipitating between 30 and $55 \%$ saturation being collected. The pellet was redissolved in the minimum volume $(2 \cdot 8 \mathrm{ml})$ of $20 \mathrm{~mm}$-potassium phosphate buffer, $\mathrm{pH} 7 \cdot 2$, at $4^{\circ} \mathrm{C}$.

Step 2: Sephadex G-75 column chromatography. The redissolved pellet was applied at $4{ }^{\circ} \mathrm{C}$ to a column $(3.8 \times 90 \mathrm{~cm})$ of Sephadex G-75, previously equilibrated with 20 mM-potassium phosphate buffer, $\mathrm{pH} 7 \cdot 2$, and eluted with similar buffer at $4{ }^{\circ} \mathrm{C}$. Fractions $(3 \mathrm{ml})$ were collected, and those with formaldehyde dehydrogenase activity were pooled $(28 \mathrm{ml})$ and concentrated at $4{ }^{\circ} \mathrm{C}$ in an Amicon ultrafiltration unit (model 12) fitted with a PM10 Diaflo membrane (Amicon, High Wycombe, Buckinghamshire) to give a final volume of $6 \mathrm{ml}$.

Step 3: Sephadex G-200 column chromatography. The material from step 2 was applied at $4{ }^{\circ} \mathrm{C}$ to a column $(3 \times 90 \mathrm{~cm})$ of Sephadex G-200, previously equilibrated with $20 \mathrm{~mm}$-potassium phosphate buffer, $\mathrm{pH} 7 \cdot 2$, and eluted with similar buffer at $4{ }^{\circ} \mathrm{C}$. Fractions $(3 \mathrm{ml})$ were collected as for step 2 and pooled.

Step 4: DEAE-cellulose treatment. DEAE-cellulose slurry $(25 \mathrm{ml}$, containing approximately $2 \mathrm{~g}$ DEAEcellulose) was slowly mixed with the pooled fractions from step $3(44 \mathrm{ml})$ at $4{ }^{\circ} \mathrm{C}$. The DEAE-cellulose had previously been extensively washed with 20 mM-potassium phosphate buffer, $\mathrm{pH} 7 \cdot 2$, and adjusted to $\mathrm{pH} 7 \cdot 2$. The mixture was slowly stirred and allowed to equilibrate for $20 \mathrm{~min}$ at $4{ }^{\circ} \mathrm{C}$, then centrifuged $\left(4^{\circ} \mathrm{C}\right)$ at $38000 \mathrm{~g}$ for $10 \mathrm{~min}$. The pellet was discarded and the supernatant was frozen by dropwise addition to liquid nitrogen, the resulting pellets being stored at $-80^{\circ} \mathrm{C}$.

Analytical procedures. Formaldehyde solutions were prepared by heating aqueous solutions of paraformaldehyde at $100^{\circ} \mathrm{C}$ for 2 to $3 \mathrm{~h}$. Formaldehyde was determined by the formaldemethone method of Frisell \& MacKenzie (1963). Routinely, formaldehyde disappearance was monitored by the acetylacetone method of Nash (1953).

Formate was determined by the method of Lang \& Lang (1972).

Protein was measured by the method of Lowry et al. (1951) using dried, crystalline bovine plasma albumin as the standard.

Polyacrylamide gel electrophoresis. The procedure was based on that of Gabriel (1971). Separating gels of $7.5 \%(\mathrm{w} / \mathrm{v})$ acrylamide were used at $\mathrm{pH} 8.8$, to which $0.2 \mathrm{ml}$ of stacking gel $(1.25 \%$, w/v, acrylamide) was added. Bromophenol blue tracking dye $(1 \mathrm{ml} ; 0.01 \%$ w/v) was added to the reservoir (electrode) buffer (50 mM-Tris/glycine, $\mathrm{pH} 8.3$ ). Electrophoresis was carried out at $2.5 \mathrm{~mA}$ per tube until the tracking dye had almost reached the base of the gel. The gels were fixed and stained with $0 \cdot 1 \%(\mathrm{w} / \mathrm{v})$ Coomassie brilliant blue $\mathrm{R}$ in $7.5 \%(\mathrm{v} / \mathrm{v})$ acetic acid $/ 46 \%(\mathrm{v} / \mathrm{v})$ methanol for 2 to $4 \mathrm{~h}$ and destained by soaking overnight in similar solvent.

The molecular weights of the HSC subunits of formaldehyde dehydrogenase were estimated by sodium dodecyl sulphate (SDS) gel electrophoresis in a $13 \%(\mathrm{w} / \mathrm{v})$ gel system. The gel buffer was $300 \mathrm{mM}-\mathrm{Tris} / \mathrm{HCl}$, $\mathrm{pH} 8.8$, and the electrode buffer was $50 \mathrm{~mm}$-Tris/glycine, $\mathrm{pH} 8 \cdot 3$, both containing $0.1 \%(\mathrm{w} / \mathrm{v})$ SDS. The samples were prepared by mixing $0.4 \mathrm{ml}$ of sample protein $(0.18 \mathrm{mg})$ with $0.5 \mathrm{ml} 10 \%(\mathrm{w} / \mathrm{v})$ SDS in $50 \mathrm{~mm}-$ Tris/ $\mathrm{HCl}$ buffer, $\mathrm{pH} 7 \cdot 8$, containing $0 \cdot 1 \%(\mathrm{v} / \mathrm{v}) 2$-mercaptoethanol and $0.1 \mathrm{ml} 60 \%(\mathrm{w} / \mathrm{v})$ sucrose solution. The mixture was heated at $100{ }^{\circ} \mathrm{C}$ in a boiling bath for $10 \mathrm{~min}$ and then cooled to $4{ }^{\circ} \mathrm{C}$. Electrophoresis and staining were done as before and the relative mobilities of the sample protein and the standard marker proteins were compared.

Activity stain. Formaldehyde dehydrogenase activity was located in unstained $(7.5 \%$, w/v) gels by incubating them in the dark with a mixture containing: $0.08 \mathrm{~g}$ nitrobluetetrazolium; $0.03 \mathrm{~g} \mathrm{NAD}^{+} ; 1.4 \mathrm{mg}$ phenazine methosulphate; $20 \mathrm{ml} 200 \mathrm{~mm}$-formaldehyde; $160 \mathrm{mg}$ HTSE (protein); $70 \mathrm{ml} 20 \mathrm{~mm}$-Tris/HCl buffer, pH 7.2. Two gels were incubated at $45^{\circ} \mathrm{C}$ for $30 \mathrm{~min}$, one being a control gel without formaldehyde, and a third gel was incubated at $30^{\circ} \mathrm{C}$ for $90 \mathrm{~min}$. Purified formaldehyde dehydrogenase HSC $(20 \mu \mathrm{g})$ was applied to each gel. 
Molecular weight determination. The molecular weight of the purified HSC of the formaldehyde dehydrogenase was determined by Sephadex G-200 gel filtration as described by Andrews (1964). The elution volumes for the purified protein and various proteins of known molecular weight were determined and their $K_{\mathrm{av}}$ values were calculated: $K_{\mathrm{av}}=\left(V_{\mathrm{e}}-V_{0}\right) /\left(V_{\mathrm{t}}-V_{0}\right)$, where $V_{\mathrm{e}}$ is the elution volume, $V_{0}$ is the void volume as determined by blue dextran, and $V_{\mathrm{t}}$ is the bed volume.

Chemicals. Biochemicals and enzymes were the best grade available and were mainly from Sigma; chemicals were supplied by BDH and Kodak. Acrylamide (pure) was obtained from Fluka, Buchs, Switzerland. DL-Glyceraldehyde 3-phosphate diethyl acetal, barium salt (obtained from Sigma) was converted to DLglyceraldehyde 3-phosphate in accordance with the supplier's instructions.

\section{RESULTS}

Presence of $N A D^{+-l i n k e d ~ f o r m a l d e h y d e ~ d e h y d r o g e n a s e ~ a c t i v i t y ~ i n ~ c r u d e ~ s o l u b l e ~ e x t r a c t s . ~}$ Soluble extracts of $M$. capsulatus strain Bath catalysed the disappearance of formaldehyde with the concomitant production of NADH when supplied with exogenous formaldehyde and $\mathrm{NAD}^{+}$. The reaction rates were unaffected by the presence of high concentrations of $\mathrm{KCN}$ which completely inhibited both the methanol oxidase activity $(0.5 \mathrm{~mm}-\mathrm{KCN})$ (Colby \& Dalton, 1976) and the $\mathrm{NAD}^{+}$-linked formate dehydrogenase (oxidase) activity $(0.05 \mathrm{~mm}-\mathrm{KCN})$ in soluble extracts of $M$. capsulatus. The possibility that a cyclic pathway of formaldehyde oxidation to $\mathrm{CO}_{2}$ and water was generating $\mathrm{NAD}(\mathrm{P}) \mathrm{H}$, as reported in a number of facultative and obligate methylotrophs (Strøm et al., 1974; Colby \& Zatman, 1975), was discounted since negligible $\mathrm{CO}_{2}$ was produced from formaldehyde in the presence of exogenous $\mathrm{NAD}^{+}$and $\mathrm{KCN}$. However, this does not discount the possibility that such a pathway operates in vivo as the enzymic requirements for such a system have been found in extracts of $M$. capsulatus (unpublished observations).

Purification of heat-sensitive component of the formaldehyde dehydrogenase. When soluble extracts of $M$. capsulatus were dialysed $\left(24 \mathrm{~h}, 4^{\circ} \mathrm{C}\right)$ against $20 \mathrm{~mm}$-potassium phosphate

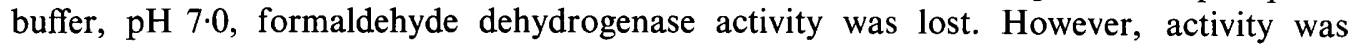
restored when the dialysed extract was supplemented with heat-treated extract (HTSE, prepared as described in Methods), which alone had no formaldehyde dehydrogenase activity. Therefore, as neither the dialysed extract nor the HTSE had formaldehyde dehydrogenase activity when assayed separately and yet regained activity when assayed together, the formaldehyde dehydrogenase must be composed of at least two components, one of which is heat-stable at $70^{\circ} \mathrm{C}$. The purification (Table 2) of the non-dialysable, heat-sensitive component of the enzyme was monitored by polyacrylamide gel electrophoresis, as shown in Fig. 1.

Products and stoicheiometry. Formate and NAD $(\mathrm{P}) \mathrm{H}$ were the only products of formaldehyde oxidation detected by the colorimetric and spectrophotometric methods described. Quantitatively, $3.90 \mu \mathrm{mol}$ formaldehyde gave rise to $3.91 \mu \mathrm{mol}$ formate and $3.36 \mu \mathrm{mol}$ NADH, suggesting a 1:1:1 molar ratio.

Substrate specificity. The following potential substrates were tested for oxidation in the standard spectrophotometric assay at $0.25,1,2.4$ and $20 \mathrm{~mm}$ : methanol, ethanol, 1-propanol, acetaldehyde, propionaldehyde, butyraldehyde, ethylene glycol, glycolaldehyde, glyoxal, glyoxylic acid, DL-glyceraldehyde and DL-glyceraldehyde 3-phosphate. Three of the compounds tested, glycolaldehyde, glyoxal and DL-glyceraldehyde, were oxidized suggesting that the enzyme is not formaldehyde-specific. There was no evidence for the occurrence of the reverse reaction on incubating $2.5 \mathrm{~mm}$-potassium formate with $0.5 \mathrm{mM}$ NADH.

Apparent $K_{\mathrm{m}}$ values, with $\mathrm{NAD}^{+}$at $0.67 \mathrm{~mm}$, were $0.68,7 \cdot 0,0.075$ and $2.0 \mathrm{~mm}$ for formaldehyde, glycolaldehyde, glyoxal and DL-glyceraldehyde, respectively, as determined by the method of Eisenthal \& Cornish-Bowden (1974). Similarly, $V_{\max }$ values for the four enzyme substrates, determined with $11 \mu \mathrm{g}$ purified HSC, were: formaldehyde (570 m-units), glycolaldehyde (73 m-units), glyoxal (281 m-units) and DL-glyceraldehyde (15 m-units). 


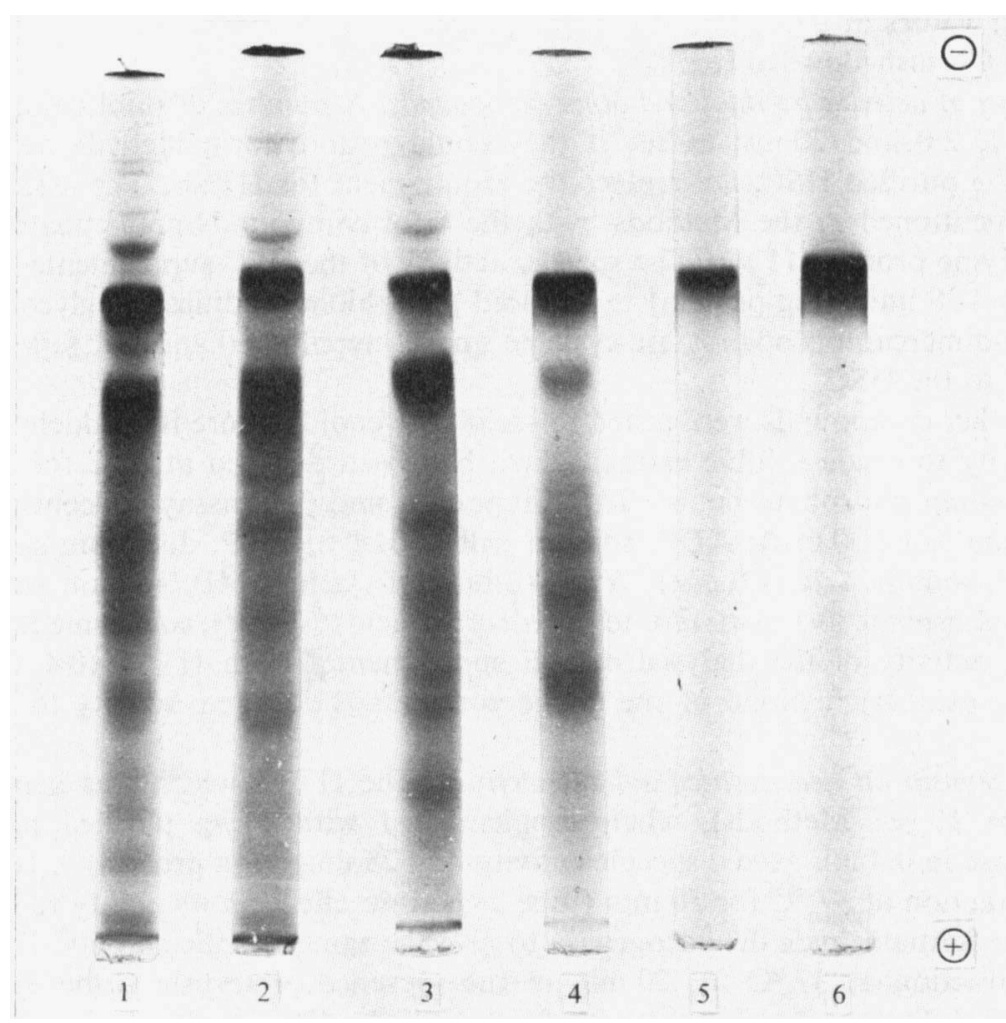

Fig. 1. Polyacrylamide gel electrophoresis of various preparations obtained during purification of the formaldehyde dehydrogenase heat-sensitive component: (1) crude soluble extract $(200 \mu \mathrm{g}$ protein); (2) after ammonium sulphate treatment (step 1) (200 $\mu$ g protein); (3) after Sephadex G-75 chromatography (step 2) (200 $\mu$ g protein); (4) after Sephadex G-200 chromatography (step 3) (100 $\mu$ g protein); (5) after DEAE-cellulose treatment (step 4) (20 $\mu \mathrm{g}$ protein); (6) after DEAEcellulose treatment (step 4) $(50 \mu \mathrm{g}$ protein). All samples were applied in $100 \mu \mathrm{l}$ and contained $6 \%(\mathrm{w} / \mathrm{v})$ sucrose. Tracking dye is at the base (anodic end) of the gels.

Table 2. Purification of heat-sensitive component of the formaldehyde dehydrogenase

Formaldehyde dehydrogenase activity was measured spectrophotometrically as described in Methods.

\begin{tabular}{|c|c|c|c|c|c|c|}
\hline Purification step & $\begin{array}{l}\text { Volume } \\
\text { (ml) }\end{array}$ & $\begin{array}{l}\text { Total } \\
\text { protein } \\
(\mathrm{mg})\end{array}$ & $\begin{array}{l}\text { Total } \\
\text { activity } \\
\text { (units) }\end{array}$ & $\begin{array}{c}\text { Specific } \\
\text { activity } \\
\text { [m-units } \\
\text { (mg pro- }_{\left.\text {tein })^{-1}\right]}\end{array}$ & Yield & $\begin{array}{l}\text { Purifica- } \\
\text { tion } \\
\text { factor }\end{array}$ \\
\hline $\begin{array}{l}\text { Soluble extract } \\
\left(\mathrm{NH}_{4}\right)_{2} \mathrm{SO}_{4}(30 \text { to } 55 \% \text { saturation } \\
\text { precipitate) }\end{array}$ & $\begin{array}{r}15 \cdot 0 \\
2.8\end{array}$ & $\begin{array}{l}720 \\
466\end{array}$ & $\begin{array}{l}60 \cdot 8 \\
45 \cdot 3\end{array}$ & $\begin{array}{l}84 \cdot 4 \\
97 \cdot 2\end{array}$ & $\begin{array}{c}100 \\
74 \cdot 5\end{array}$ & $\begin{array}{l}1 \cdot 0 \\
1.2\end{array}$ \\
\hline Sephadex G-75 & $6 \cdot 0$ & 370 & $48 \cdot 6$ & $131 \cdot 5$ & $79 \cdot 9$ & 1.6 \\
\hline Sephadex G-200 & $44 \cdot 0$ & 88 & $89 \cdot 1$ & $1012 \cdot 5$ & $146 \cdot 5$ & $12 \cdot 0$ \\
\hline DEAE-cellulose & $39 \cdot 0$ & $17 \cdot 6$ & $75 \cdot 3$ & $4278 \cdot 4$ & $123 \cdot 8$ & $50 \cdot 7$ \\
\hline
\end{tabular}

Electron acceptors. Various artificial and physiological electron acceptors were tested with the purified formaldehyde dehydrogenase. Phenazine methosulphate (PMS) (0.7 mM), 2,6-dichlorophenolindophenol (DCPIP) $(0.2 \mathrm{~mm})$, PMS (0.7 mM) plus DCPIP ( $0.2 \mathrm{~mm})$, $\mathrm{K}_{3} \mathrm{Fe}(\mathrm{CN})_{6}(2.0 \mathrm{~mm}), \mathrm{K}_{3} \mathrm{Fe}(\mathrm{CN})_{6}(2.0 \mathrm{~mm})$ plus PMS $(1.0 \mathrm{~mm}), \mathrm{K}_{3} \mathrm{Fe}(\mathrm{CN})_{6}(2.0 \mathrm{~mm})$ plus $\mathrm{NAD}^{+}(0.67 \mathrm{mM})$, and cytochrome $c(0.1 \mathrm{mM})$ did not act as electron acceptors. $\mathrm{NAD}^{+}$ 
and NADP + both acted as electron acceptors and, with formaldehyde at $2.5 \mathrm{~mm}$, gave apparent $K_{\mathrm{m}}$ values of 0.063 and $0.155 \mathrm{mM}$, respectively, as determined by the method of Eisenthal \& Cornish-Bowden (1974).

Restoration of activity by thiol and other compounds. A number of thiol compounds were tested at $0 \cdot 1,2.0$ and $20 \mathrm{~mm}$ to see if they could restore formaldehyde dehydrogenase activity to the purified HSC, i.e. replace the requirement for HTSE. The assays were performed as mentioned in the Methods, with the thiol compounds preincubated for 5 min with the enzyme protein $(11 \mu \mathrm{g})$. The specific activity of the HSC supplemented with HTSE $(0.4 \mathrm{ml})$ was 4.28 units (mg protein $)^{-1}$. Reduced glutathione, sodium thioglycollate, dithiothreitol, 2,3-dimercaptopropanol, DL-cysteine and 2-mercaptoethanol all failed to restore any activity to the HSC.

Various other compounds were tested to see if they could restore formaldehyde dehydrogenase activity to crude soluble extract which had been dialysed at $4{ }^{\circ} \mathrm{C}$ for $24 \mathrm{~h}$ against $20 \mathrm{~mm}$-potassium phosphate buffer. The compounds and final assay concentrations were: AMP, sodium salt (1.0 mM); ADP, sodium salt (1.0 mM); ATP, disodium salt ( $1.0 \mathrm{~mm})$; cyclic AMP, sodium salt $(1.0 \mathrm{mM}) ; N^{6}, O^{2 \prime}$-dibutyryl cyclic AMP, sodium salt $(1.0 \mathrm{~mm})$; pyridoxal 5-phosphate $(0.1 \mathrm{mM}) ; d l$-L-tetrahydrofolic acid $(0.1 \mathrm{mM})$; coenzyme $\mathrm{B}_{12}(0.05 \mathrm{mM})$. The specific activity of the dialysed extract supplemented with HTSE $(0 \cdot 4 \mathrm{ml})$ was 84.4 m-units (mg protein) $)^{-1}$. None of the above compounds restored activity to the dialysed extract.

Effect of trypsin on heat-treated soluble extract. The HTSE which was kept on ice for $30 \mathrm{~min}$ (tube 1, see Methods), when supplemented with $11 \mu \mathrm{g}$ purified formaldehyde dehydrogenase in $0.4 \mathrm{ml}$, gave a specific activity of 4.28 units (mg protein) ${ }^{-1}$. Incubation of the HTSE fraction at $37^{\circ} \mathrm{C}$ for $30 \mathrm{~min}$ (tube 2) had no effect on its ability to complement with purified formaldehyde dehydrogenase to give the same specific activity. Incubation of the HTSE fraction at $37^{\circ} \mathrm{C}$ for $30 \mathrm{~min}$ in the presence of trypsin (tube 3) completely abolished its ability to complement with formaldehyde dehydrogenase. Furthermore, the HTSE fraction that had been incubated at $37^{\circ} \mathrm{C}$ for $30 \mathrm{~min}$ in the presence of trypsin plus an excess of trypsin inhibitor (tube 4 ) restored complete activity to the formaldehyde dehydrogenase enzyme. These results suggest that the cofactor in the HTSE fraction was trypsin-sensitive.

Activity stain. After polyacrylamide gel electrophoresis of the purified HSC of the formaldehyde dehydrogenase, the unstained gels were immersed in an activity stain or in Coomassie blue stain as described in the Methods. The gel incubated at $45^{\circ} \mathrm{C}$ for $30 \mathrm{~min}$ in the complete active stain and the gel incubated at $30^{\circ} \mathrm{C}$ for $90 \mathrm{~min}$ both showed a single active stained band. The active stained bands had identical electrophoretic mobility to the single band found on similar gels stained with Coomassie blue. The gel incubated with the activity stain at $30^{\circ} \mathrm{C}$ required three times as long as a similar gel incubated at $45^{\circ} \mathrm{C}$ to develop a band of equal intensity. The gel incubated at $45{ }^{\circ} \mathrm{C}$ with the activity stain minus formaldehyde gave no equivalent band.

Absorption spectrum. The visible and ultraviolet absorption spectrum of the purified HSC revealed no characteristic absorption peaks, other than the absorption at $280 \mathrm{~nm}$.

Inhibition studies. Various metal-chelating agents were tested as potential inhibitors of enzyme activity at $2.5 \mathrm{~mm}$ : thiourea, thioacetamide, diethyldithiocarbamate, 2,2'-bipyridine, neocuproine, imidazole, 1,10-phenanthroline, acriflavin, 8-hydroxyquinoline and KCN. Only $2,2^{\prime}$-bipyridine (10\% inhibition) and thiourea (10\% inhibition) caused any inhibition.

A number of substrate analogues (methanol, ethanol, 1-propanol, acetaldehyde and propionaldehyde) were also tested as potential inhibitors at $2.5 \mathrm{~mm}$, but only methanol $(5 \%$ inhibition) had any inhibitory effect.

Of various thiol reagents tested (Table 3), iodoacetic acid and iodoacetamide caused little inhibition of activity, whereas $N$-ethylmaleimide caused around $60 \%$ inhibition at $2.0 \mathrm{~mm}$. $p$-Hydroxymercuribenzoate completely inhibited activity at $1.0 \mathrm{mM}$ but was totally ineffec- 
Table 3. Inhibition of formaldehyde dehydrogenase activity by thiol reagents

Activity was measured spectrophotometrically as described in Methods; each potential inhibitor was preincubated with the enzyme for $5 \mathrm{~min}$. The uninhibited specific activity of the enzyme was $4 \cdot 28$ units (mg protein) ${ }^{-1}$.

\begin{tabular}{lcc}
\multicolumn{1}{c}{ Reagent } & $\begin{array}{c}\text { Final concn } \\
(\mathrm{mM})\end{array}$ & $\begin{array}{c}\text { Inhibition } \\
(\%)\end{array}$ \\
Iodoacetic acid & $2 \cdot 0$ & 14 \\
& $1 \cdot 0$ & 8 \\
Iodoacetamide & $0 \cdot 1$ & 0 \\
& $2 \cdot 0$ & 14 \\
$N$-Ethylmaleimide & $1 \cdot 0$ & 28 \\
& $0 \cdot 1$ & 0 \\
-Hydroxymercuribenzoate & $2 \cdot 0$ & 59 \\
& $1 \cdot 0$ & 50 \\
5,5'-Dithiobis(2-nitrobenzoic & $0 \cdot 1$ & 0 \\
acid) & $1 \cdot 0$ & 100 \\
& $0 \cdot 1$ & 0 \\
& $0 \cdot 1$ & 9
\end{tabular}

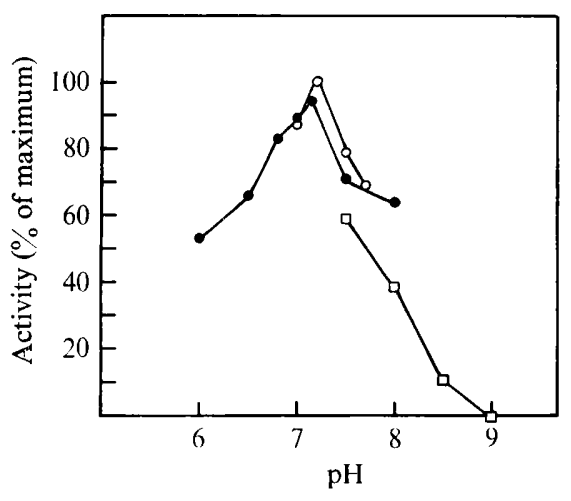

Fig. 2

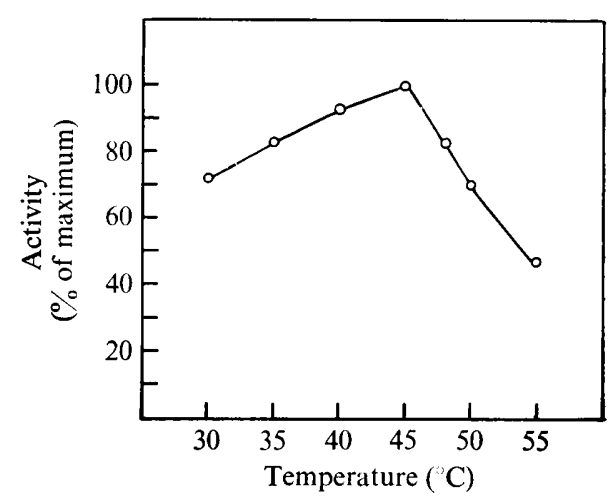

Fig. 3

Fig. 2. Effect of $\mathrm{pH}$ on formaldehyde dehydrogenase activity. Activity was measured spectrophotometrically as described in Methods; the maximum specific activity was $4 \cdot 28$ units (mg protein $)^{-1}$. All buffers were $20 \mathrm{~mm}$ : 0 , potassium phosphate; $\mathrm{O}$, Tris $/ \mathrm{HCl} ; \square$, tetrasodium pyrophosphate $/ \mathrm{HCl}$.

Fig. 3. Effect of temperature on formaldehyde dehydrogenase activity. Activity was measured spectrophotometrically as described in Methods; the maximum specific activity was 4.28 units (mg protein) $)^{-1}$.

tive at $0 \cdot 1 \mathrm{~mm}$. 5,5'-Dithiobis(2-nitrobenzoic acid) caused little inhibition at $0 \cdot 1 \mathrm{~mm}$ and could not be tested at a higher concentration due to absorption by the compound at $340 \mathrm{~nm}$.

Effect of $\mathrm{pH}$ and temperature. The optimum $\mathrm{pH}$ for formaldehyde dehydrogenase activity was $\mathrm{pH} 7.2$ (Fig. 2). The enzyme was equally active in phosphate buffer or Tris/HCl-buffer at $\mathrm{pH} 7 \cdot 2$. Maximum enzyme activity occurred at $45^{\circ} \mathrm{C}$ (Fig. 3), with the reaction rate deteriorating rapidly at higher temperatures. After the usual preincubation of an assay mixture at $45^{\circ} \mathrm{C}$, no enzyme activity was lost on further incubation at $45^{\circ} \mathrm{C}$ for at least $10 \mathrm{~min}$ before formaldehyde addition.

Molecular weight and subunit size. The molecular weight of the HSC of the formaldehyde dehydrogenase from $M$. capsulatus was estimated by gel filtration to be 115000 (Fig. 4). SDS-polyacrylamide gel electrophoresis (Fig. 5) gave a value of 57000 for the subunit molecular weight of the HSC, suggesting that the enzyme is a dimer. 


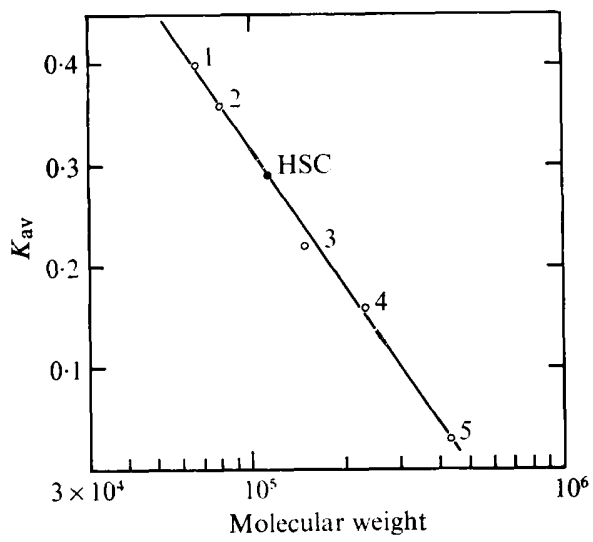

Fig. 4

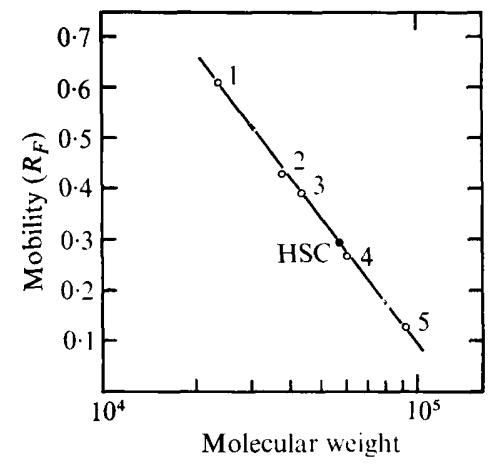

Fig. 5

Fig. 4. Molecular weight estimation of the heat-sensitive component (HSC) of formaldehyde dehydrogenase on a Sephadex G-200 column (see Methods for details). Molecular weight standards were: (1) malate dehydrogenase $(67000)$; (2) alkaline phosphatase $(80000)$; (3) alcohol dehydrogenase $(150000) ;(4)$ catalase $(232000) ;(5)$ ferritin (443000).

Fig. 5. Sodium dodecyl sulphate gel electrophoresis of the heat-sensitive component (HSC) of formaldehyde dehydrogenase (see Methods for details). Molecular weight standards were: (1) $\alpha$-chymotrypsinogen A (23700); (2) alcohol dehydrogenase (37500); (3) ovalbumin (43000); (4) catalase $(60000) ;(5)$ phosphorylase a (92500).

\section{DISCUSSION}

The formaldehyde dehydrogenase found in $M$. capsulatus is similar to the enzyme found in Bacterium 4B6 (Colby \& Zatman, 1973), i.e. type 3 (Table 1), but $M$. capsulatus is the first methane-oxidizing bacterium found to possess a glutathione-independent, NAD $(P)^{+}-$ linked formaldehyde dehydrogenase. Possessing such an enzyme is of great advantage to the organism as its growth yield, when growing on methane as the sole source of carbon and energy, could be exclusively NAD(P)H-dependent (Anthony, 1978). This apparent deficiency of reducing power arises because $\mathrm{NAD}(\mathrm{P}) \mathrm{H}$ is required for methane mono-oxygenase activity (Colby \& Dalton, 1976) and, theoretically, for the assimilation of formaldehyde into cell material (Van Dijken \& Harder, 1975), but no NAD(P)H is generated from the oxidation of methane to formaldehyde. Although $\mathrm{NAD}(\mathrm{P}) \mathrm{H}$ cannot be generated from methanol dehydrogenase activity, reducing equivalents [other than $\mathrm{NAD}(\mathrm{P}) \mathrm{H}$ ] are produced and could theoretically give a $\mathrm{P} / \mathrm{O}$ ratio of 2 . In some methane oxidizers, e.g. Methylosinus trichosporium $\mathrm{OB} 3 \mathrm{~b}$, the methanol dehydrogenase coupled with cytochrome $c$ acts directly as the reducing agent for methane mono-oxygenase activity negating the need for NAD(P)H (Tonge, Harrison \& Higgins, 1977). This does not occur in M. capsulatus (Colby \& Dalton, 1976). Therefore, in $M$. capsulatus the amount of reducing power generated by the complete oxidation of methane to carbon dioxide is critical, as this has to satisfy the deficiency of the cell's reducing power. In most methylotrophs, the only source of NAD(P)H from the complete oxidation of methane is the final oxidation step, formate to carbon dioxide and water, catalysed by formate dehydrogenase. Hence, an NAD(P)+-linked formaldehyde dehydrogenase would greatly reduce the percentage of the carbon substrate needing to be completely oxidized to carbon dioxide in order to generate the reducing power required for cellular biosynthesis. If a reverse electron transport system was operative in this organism, the problem of an $\mathrm{NAD}(\mathrm{P}) \mathrm{H}$ deficiency could be somewhat alleviated, due to the conversion of 'excess' ATP to NAD(P)H. However, reverse electron flow has not been unequivocally demonstrated in methylotrophs (see Dalton, 1977).

Patel \& Hoare (1971) were unable to show the presence of either a DCPIP-linked or 
$\mathrm{NAD}(\mathrm{P})^{+}$-linked formaldehyde dehydrogenase in extracts of $M$. capsulatus strain Texas, which supports the idea, previously suggested (Stirling \& Dalton, 1977), that there is a more radical difference between the Bath and Texas strains than their taxonomic relationship implies.

The presence of potassium cyanide in the formaldehyde dehydrogenase assays totally inhibited formate dehydrogenase activity and partially inhibited the NAD(P)H oxidase activity present. It is thought that the apparent increase in the yield during purification of the HSC was due to the removal of the cyanide-resistant NAD(P)H oxidase activity originally present in the crude soluble extracts.

The substrate specificity results show that the NAD(P)+-linked formaldehyde dehydrogenase from $M$. capsulatus is not absolutely specific and can oxidize other aldehydes. However, as only formaldehyde, glyoxal, glycolaldehyde and glyceraldehyde are oxidized, the range of substrate aldehydes is limited compared with the variety of aldehydes oxidized by enzymes isolated from other methylotrophic bacteria. Generally, non-specific aldehyde dehydrogenases oxidize a much wider range of aldehydes in addition to those listed above, including acetaldehyde, propionaldehyde, butyraldehyde, glyoxylate and glyceraldehyde 3-phosphate.

The apparent substrate specificity of the formaldehyde dehydrogenase of $M$. capsulatus could be further restricted if the activity obtained with glyceraldehyde is a result of contamination by formaldehyde, since a $25 \mathrm{~mm}$ solution of DL-glyceraldehyde was found to contain approximately $60 \mu \mathrm{M}$-formaldehyde, as determined by the method of Chrastil \& Wilson (1975). The authors claim that no reactivity with DL-glyceraldehyde is obtained with their colorimetric assay.

The $K_{\mathrm{m}}$ and $V_{\max }$ values obtained with glyoxal could be greater than quoted because of the very narrow range of substrate concentrations which gave activity, apparently due to potent substrate or product inhibition. Hence, the apparently greater affinity for the enzyme shown by glyoxal compared with formaldehyde could be reduced or even reversed. On the evidence of the $K_{\mathrm{m}}$ values, glycolaldehyde and glyceraldehyde appear to be much poorer substrates than formaldehyde for the enzyme.

The lack of activity obtained when the purified HSC was supplemented with various thiol compounds suggests that there is no requirement for a thiol compound for enzyme activity and no formyl/thiol compound is produced during formaldehyde oxidation in M. capsulatus. Hence, $M$. capsulatus is unlike the yeast Hansenula polymorpha whose formaldehyde dehydrogenase requires glutathione for activity and produces 5-formylglutathione from the oxidation of formaldehyde (Van Dijken et al., 1976).

The lack of formaldehyde dehydrogenase activity in dialysed, crude soluble extract assayed in the presence of various potential cofactors suggests that none of the common, low molecular weight physiological cofactors, such as AMP, ATP, cyclic AMP etc., are required for activity in $M$. capsulatus.

The sensitivity of the HTSE to the endopeptidase trypsin suggests that the enzyme component/cofactor present in HTSE and required to restore activity to the purified HSC is either a protein or a peptide. Since the component present in HTSE will restore activity to dialysed crude soluble extract, it is likely that the HTSE compound is itself dialysable and is presumably a polypeptide, although attempts to purify this component have so far met with little success. The enzyme showed almost uniform resistance to metal-binding/ chelating agents, implying either the non-involvement of a metal(s) or that it contains a metal-ion complex well shielded from attack by such agents.

The effect of thiol reagents on formaldehyde dehydrogenase activity was variable. The total inhibition obtained with $p$-hydroxymercuribenzoate at $1 \mathrm{~mm}$ was not surprising, for this effective thiol reagent is known to inhibit enzymes at micromolar concentrations (Trudinger, 1969). The weak inhibitions observed in the presence of the less potent thiol reagents, iodoacetic acid and iodoacetamide, support the view that no formyl/thiol compound is 
formed as an intermediate during the oxidation of formaldehyde, since one would expect potent inhibition of such a reaction to occur with the concentrations of reagents tested. However, there are obviously thiol groups present in the formaldehyde dehydrogenase enzyme which are vulnerable to the action of thiol reagents and this would not be unexpected with a major component of the enzyme having a molecular weight of over $10^{5}$.

This work was funded through an S.R.C. Research Grant to Howard Dalton and an S.R.C. Studentship to David I. Stirling. We thank Mr P. P. Taylor for his excellent technical assistance and Dr J. Colby for helpful discussions.

\section{REFERENCES}

ANDREws, P. (1964). Estimation of the molecular weight of proteins by Sephadex gel-filtration. Biochemical Journal 91, 222-233.

ANTHONY, C. (1978). The prediction of growth yields in methylotrophs. Journal of General Microbiology 104, 91-104.

ANTHONY, C. \& ZATMAN, L. J. (1964). The microbial oxidation of methanol. 2. The methanol-oxidizing enzyme of Pseudomonas sp. M27. Biochemical Journal 92, 614-621.

Boulton, C. A. \& Large, P. J. (1977). Synthesis of certain assimilatory and dissimilatory enzymes during bacterial adaptation to growth on trimethylamine. Journal of General Microbiology 101, 151-156.

Chrastil, J. \& Wilson, J. A. (1975). A sensitive colorimetric method for formaldehyde. Analytical Biochemistry 63, 202-207.

Colby, J. \& Dalton, H. (1976). Some properties of a soluble methane mono-oxygenase from Methylococcus capsulatus strain Bath. Biochemical Journal 157, 495-497.

Colby, J. \& Zatman, L. J. (1973). Trimethylamine metabolism in obligate and facultative methylotrophs. Biochemical Journal 132, 101-112.

Colby, J. \& Zatman, L. J. (1975). Enzymological aspects of the pathways for trimethylamine oxidation and $C_{1}$ assimilation in obligate methylotrophs and restricted facultative methylotrophs. Biochemical Journal 148, 513-520.

Colby, J., Stirling, D. I. \& Dalton, H. (1977). The soluble methane mono-oxygenase of Methylococcus capsulatus (Bath). Its ability to oxygenate $n$-alkanes, $n$-alkenes, ethers and alicyclic, aromatic and heterocyclic compounds. Biochemical Journal 165, 395-402.

Dalton, H. (1977). Ammonia oxidation by the methane oxidising bacterium Methylococcus capsulatus strain Bath. Archives of Microbiology 114, 273-279.

Dalton, H. \& Whittenbury, R. (1976). The acetylene reduction technique as an assay for the nitrogenase activity in the methane oxidizing bacterium Methylococcus capsulatus strain Bath. Archives of Microbiology 109, 147-151.

Eisenthal, R. \& CoRnish-Bowden, A. (1974). The direct linear plot. A new graphical procedure for estimating enzyme kinetic parameters. Biochemical Journal 139, 715-720.

Frisell, W. R. \& MacKenzie, C. G. (1963). The determination of formaldehyde and serine in biological systems. Methods of Biochemical Analysis 6 (2nd edn), 63-77.

GabRIEL, O. (1971). Analytical disc gel electrophoresis. Methods in Enzymology 22, 565578.

Hampton, D. \& Zatman, L. J. (1973). The metabolism of tetramethylammonium chloride by Bacterium 5H2. Biochemical Society Transactions 1, 667-668.

Harrington, A. A. \& Kallio, R. E. (1960). Oxidation of methanol and formaldehyde by Pseudomonas methanica. Canadian Journal of Microbiology 6, 1-7.

Johnson, P. A. \& QuAyle, J. R. (1964). Microbial growth on $\mathrm{C}_{1}$ compounds. 6 . Oxidation of methanol, formaldehyde and formate by methanol-grown Pseudomonas AM1. Biochemical Journal 93, 281-290.

Kung, H. F. \& WAGNeR, C. (1970). Oxidation of $C_{1}$ compounds by Pseudomonas sp. MS. Biochemical Journal 116, 357-365.

LANG, E. \& LANG, H. (1972). Spezifische Farbreaktion zum direkten Nachweis der Ameisensäure. Zeitschrift für analytische Chemie 260, 8-10.

LARGe, P. J. \& QUAYLE, J. R. (1963). Microbial growth on $\mathrm{C}_{1}$ compounds. 5. Enzyme activities in extracts of Pseudomonas AM1. Biochemical Journal 87, 386-396.

Lowry, O. H., Rosebrough, N. J., FarR, A. L. \& RANDALL, R. J. (1951). Protein measurement with the Folin phenol reagent. Journal of Biological Chemistry 193, 265-275.

Menta, R. J. (1973). Studies on methanol-oxidizing bacteria. II. Purification and properties of methanol dehydrogenase from Pseudomonas $\mathrm{RJ}_{1}$. Antonie van Leeuwenhoek 39, 303-312.

MEHTA, R. J. (1975). A novel inducible formaldehyde dehydrogenase of Pseudomonas sp. $\left(\mathrm{RJ}_{1}\right)$. Antonie van Leeuwenhoek 41, 89-95.

NASH, T. (1953). The colorimetric estimation of formaldehyde by means of the Hantzsch reaction. Biochemical Journal 55, 416-421.

O'Connor, M. L. \& Hanson, R. S. (1977). Enzyme regulation in Methylobacterium organophilum. Journal of General Microbiology 101, 327332.

Patel, R. N. \& Felix, A. (1976). Microbial oxi da tion of methane and methanol: crystallization and properties of methanol dehydrogenase from Methylosinus sporium. Journal of Bacteriology 128, 413-424. 
Patel, R. N. \& Hoare, D. S. (1971). Physiological studies of methane and methanol-oxidizing bacteria: oxidation of C-1 compounds by Methylococcus capsulatus. Journal of Bacteriology 107, 187-192.

Sperl, G. T., Forrest, H.S. \& Gibson, D. T (1974). Substrate specificity of the purified primary alcohol dehydrogenase from methanol-oxidizing bacteria. Journal of Bacteriology 178, 541-550.

Stirling, D. I. \& Dalton, H. (1977). Effect of metal-binding agents and other compounds on methane oxidation by two strains of Methylococcus capsulatus. Archives of Microbiology 114, 7176.

Strøm, T., Ferenci, T. \& Quayle, J. R. (1974). The carbon assimilation pathways of Methylococcus capsulatus, Pseudomonas methanica and Methylosinus trichosporium (ОВ3в) during growth on methane. Biochemical Journal 144, 465-476.

Tonge, G. M., Harrison, D. E. F. \& Higgins, I. J (1977). Purification and properties of the methane mono-oxygenase enzyme system from Methylosinus trichosporium Ов 3 b. Biochemical Journal 161, 333-344.

Trudinger, P. A. (1969). Thiol reagents. In Data for Biochemical Research, 2nd edn, pp. 388-395 Edited by R. M. C. Dawson, D. C. Elliot, W. H Elliot \& K. M. Jones. London: Oxford University Press.

VAN Dijken, J. P. \& Harder, W. (1975). Growth yields of micro-organisms on methanol and methane. A theoretical study. Biotechnology and Bioengineering 17, 15-30.

Van Dijken, J. P., Oostra-Demkes, G. T., Otto, R. \& HARDER, W. (1976). S-Formylglutathione: the substrate for formate dehydrogenase in methanolutilizing yeasts. Archives of Microbiology 111, 77-83.

Whittenbury, R., Phillips, K. C. \& Wilkinson, J. F. (1970). Enrichment, isolation and some properties of methane-utilizing bacteria. Journal of General Microbiology 61, 205-218. 